\title{
The Development of Corporate Social Responsibility in the Context of Overcoming a Welfare State Crisis: a Theoretical and Empirical Analysis
}

\author{
Nadiia Grazhevska (iD https://orcid.org/0000-0003-2549-8055 \\ Professor, Department of Economic Theory, Macro- and Microeconomics \\ Taras Shevchenko National University of Kyiv, Kyiv, Ukraine \\ e-mail: nadiia.hrazhevska@gmail.com
}

\begin{abstract}
Alla Mostepaniuk (iD https://orcid.org/0000-0001-5327-2534
Ph.D., Department of Economic Theory, Macro- and Microeconomics

Taras Shevchenko National University of Kyiv, Kyiv, Ukraine

e-mail: a.mostepaniuk@gmail.com
\end{abstract}

\section{Abstract}

The current social crisis, caused by the negative consequences of globalization, labor migration, and an aging population, requires the state's role in economic and social spheres to be reconsidered. In order to achieve and maintain sustainable economic growth, the pressing social problems, such as poverty, hunger, discrimination, and the unequal distribution of income, should be solved. Under these circumstances, the paper investigates the process of forming a welfare state to evaluate the role of current states in this period of social crisis. To achieve the aim, the following methods were used: historical and systematic analysis of the scientific literature and socio-economic conditions of the evolution of theoretical approaches of the welfare state, and the causes and characteristics of the present social crisis; cluster analysis of European countries to find similar patterns based on the level of corporate social responsibility (CSR) development, state social expenditures, and the government budget balance. The paper contains a detailed analysis and discussion of the formation of a welfare state. The study concludes that the process of delegating some state social services to the private sector in the form of CSR can be considered an efficient mechanism to eliminate and overcome the current social crisis through the accumulation of social capital. At the same time, the results of the cluster analysis of European countries 
demonstrated the importance of CSR development as a compensator for the negative effects of a public welfare crisis and for solving pressing social problems in most European countries. Specific features of post-socialist countries in the context of social orientation of state policy and the development of CSR are highlighted.

Keywords: welfare state, social crisis, social policy, social protection, corporate social responsibility

JEL: I38, M14

\section{Introduction}

According to the United Nations General Assembly Resolution “Transforming our World: the 2030 Agenda for Sustainable Development”, humanity's overarching goals at the turn of the millennium are overcoming poverty, ensuring health care, access to education, decent working conditions, improving the well-being of the population, and reducing income inequality (United Nations 2015). The state should play a crucial role in redistributing income, providing social services, social protection and the insurance of citizens, financial support for the incapable population, and guaranteeing proper working conditions and the minimum level of remuneration. At the same time, the social-oriented transformation of developed countries shows that the escalation of globalization processes in the last third of the twentieth century contributed to the completion of a long cycle of affirming the welfare state in these countries. The dramatic change in the conditions of socio-economic development ushered in a new stage in the evolution of the welfare state, which is largely determined by the global transformation of world economic processes.

\section{"Welfare state" concept development}

The first attempt to determine the specific features of a welfare state was made in the nineteenth century by socialist scholars. The introduction of such a concept was linked to the need to overcome the negative effects of the Industrial Revolution, namely, rising unemployment, increasing poverty, and deepening social contradictions and imbalances. According to Geissler, the need for a socially-oriented state policy during this period was caused by the conflict between labor and capital. The aim of this policy was, therefore, to improve the working conditions of workers, ensure full employment and social security, promote the growth of capitalist production, mitigate socio-economic crises, prevent the elimination of jobs, and increase the status of employees (Geissler 1980).

At the same time, the dangers of impoverishing the population and the despair in the state encourage hired workers to commit crime, in the first place, against the 
rich. This was extremely undesirable and dangerous to the authorities. Robert von Mohl drew attention to certain threats and "restrictions" of social support for the population, which may facilitate the transition from work or entrepreneurship to passive state aid (Chapman 2007). In contrast, Lorenz von Stein emphasized the importance of social support in empowering the working class to raise capital and become self-sufficient, which cannot be achieved without the state's help aimed at strengthening the middle class (Gordon 1991).

The Great Depression had a significant impact on the theory and practice of state social policy. During this period in Western Europe, about 30 million people were unemployed. The middle-class, in particular, suffered as their welfare level fell below the poverty line. At the same time, in the USA, industrial production declined by $50 \%$, there were about 15 million unemployed, more than 5,000 banking institutions closed, and natural population growth declined significantly (Smiley, n.d.). To solve these problems, the governments of the world's leading countries substantially transformed their social policies. Thus, according to Roosevelt's «First New Deal,» working hours were increased in the USA, a minimum wage was set, overtime was paid, labor relations were established through trade union organizations, and the unemployed were involved in public works (e.g., the construction of roads and bridges, infrastructure facilities). Subsequently, Roosevelt's "Second New Deal" strengthened the state's social protection system by establishing a social insurance scheme and expanding the social rights and guarantees of employees (Smiley, n.d.).

The Great Depression and its aftermath prompted economists to reconsider the basics of classical economic theory. The founder of macroeconomic theory, Keynes, argued the concept of state influence in his classic work "The General Theory of Employment, Interest and Money" (Keynes 1936). Considering the pace of economic development at the time, he proved that a market economy is not a self-regulatory system, and economic equilibrium is not the result of the functioning of the free market. Therefore, the state should intervene in the market during times of crisis or recession by stimulating aggregate demand as a basis for the push for economic growth. According to Keynesian theory, aggregate demand can be increased by reducing the interest rate that will stimulate entrepreneurship; increasing state budget expenditures for the purchase of goods and services, public works; redistributing the national income in favor of the low-income population; and introducing a progressive tax system (Keynes 1936). All these state regulation measures were aimed at increasing employment and the income of the population to stimulate aggregate demand and economic growth. The implementation of these recommendations in the state regulation of the economy and the social relations of most developed countries contributed to the successful overcoming of the crisis, the recovery, and the development of national economies until the recession of the 1970s.

The theory and practice of forming and implementing a "social market economy" model, which is based on the principles of ordoliberalism in post-World War II Germany, is essential. The theory of the social market economy was established by Eucken and was based on ensuring openness of the market and free competition, freedom 
of all business transactions, private property, and businesses taking full responsibility for the results of their activities (Kolev et al. 2014). At the same time, in "Social market economy" (1947), Müller-Armack determined that the distinctiveness of the social market economy is the combination of market freedoms with the principle of social equalization. In other words, the task of public policy is to ensure conditions of free competition and the equalization of income through rational fiscal policy. This policy provides financial support to the population who have suffered losses as a result of the war, payments and subsidies to socially disadvantaged groups, and the provision of social security and preferential loans, among others (Rooks 2019).

These principles were put into practice by German Chancellor Ludwig Erhard, and it led to the so-called "German Economic Miracle." Post-war Germany achieved economic growth thanks to the state's active socio-economic policy to ensure free competition and control the redistribution of national income to prevent significant social differentiation and promote full employment (Volker 2015).

After World War II , the welfare state concept was ensured at the legislative level in the Federal Republic of Germany, France, Japan, Italy, Spain, Portugal, and Sweden. The main goal of public policy in those countries was to regulate the social, political, and economic life of society to provide a sufficient level of social protection for all citizens, social justice, and solidarity of the state and the citizen (Zadoia and Palladin 2017). It was about implementing the principles of equal distribution of income and responsibility that cannot be achieved without government intervention. The welfare state's main tasks were guaranteeing a minimum household income, preventing social risks, creating satisfactory living conditions for citizens, promoting social equality and fairness (Aravacik 2018).

Consequently, in the post-war period, European countries raised public expenditures to boost the economy. Thus, in Germany, public expenditures reached 27\% of GDP in 1950, 30\% in 1955, and 50.3\% in 1975. Similar changes occurred in other European countries. In particular, in France, the level of public expenditures was 24.1\% of GDP in 1950 (Mauro et al. 2013). At the same time, the unemployment rate was decreasing. In Germany, it was $0.4 \%$ in 1962, and it remained at such a low level until the economic crisis of the 1970s (OECD Data, n.d.).

Competition with the socialist countries and the deployment of the social democratic movement in Europe had a significant influence on Western countries' social policy during this period. It started with the creation of the Social Democratic Party of Germany in 1875. Later, the Social Democratic Party was formed in Denmark in 1876, Austria-Hungary in 1889, and Italy in 1892. Initially, most of these parties' programs focused on reforming the existing social order towards forming a welfare state. After the Second World War, the Social Democratic parties significantly strengthened their influence and authority. In the second half of the twentieth century, they headed the governments of almost all Western European countries that launched large-scale nationalization programs (the Labour Government in Great Britain, the Social Democratic Government of Germany, and the Socialist Government of France). 
The economic literature now distinguishes three welfare state models which were formed in different groups of countries under the influence of the specifics of their historical and institutional development:

1) the liberal model, based on private property and a market economy; the provision of certain social services are transferred to the private sector in the form of private insurance and private pension funds; financial social assistance is provided to the poorest citizens, and the level of well-being of the population depends solely on their own efforts and activities. This model aims to minimize economic inequality and is used in the United States, Canada, the United Kingdom, Ireland, and Australia;

2) the conservative model, based on a socially-oriented market economy, where the state is called upon to minimize the inequalities that have arisen as a result of the economy's market conditions by providing access to education, financial assistance in old age and sickness, and affordable housing, among others; the main task of the state is to ensure equal opportunities for all citizens whose personal well-being depends on their own aspirations and efforts; state policy aims at the redistribution of material goods, while the sum of social payments depends on the amount of income, insurance payments, etc. This model is followed by Austria, France, Germany, and Italy;

3) the social-democratic model, where social services are provided exclusively by the state sector, and sufficient budget revenues are ensured by high taxes and the profits of state-owned enterprises; the state seeks to reduce the income gap and ensure equal rights for all citizens, promote full employment, provide decent working conditions, protect the environment, and make medicine accessible. Countries that follow this model include Sweden, Switzerland, Norway, Finland, Denmark, and the Netherlands (Esping-Andersen 1990).

An important stage in the evolution of these welfare state models was the economic crisis of the 1970s, which affected all developed countries. According to some critics, the crisis was the result of Keynesian policies and excessive government intervention in the economy, which failed to counteract the negative impact of the following three factors: (1) the collapse of the Bretton Woods monetary system (1971); (2) the oil crisis (1973); (3) the stock market crises (1973-1974). As a result, the US and Western Europe saw a significant reduction in production, and rising unemployment and prices. In particular, in Germany, more than one million workers lost their jobs, the volume of gross national product decreased by $4 \%$, and the volume of industrial production fell by $7.5 \%$. In the United States, the unemployment rate increased by $4 \%$ from $1974-$ 1975, reaching 9\% (Zarnowitz and Moore 1977; Urquhart and Hewson 1983).

These crises and shocks helped to transform the socio-economic policies of the world's leading countries toward liberalizing the economy and reducing many social programs. In particular, the Thatcher Government's neo-conservative policy in the UK was aimed at overcoming inflation, curbing public intervention in the economy and social sphere, reducing social sector funding and narrowing down the bureaucrat- 
ic apparatus, and transferring unprofitable state-owned enterprises to private ownership (Middleton 1996). Reagan led the reorientation of the US government policy towards tax cuts to promote modernization and private sector growth. Public demand and consumption increased, public expenditures were redistributed in favor of technological development, and social expenditures were reduced (Niskanen 1988).

\section{Crisis of the welfare state}

At the end of the twentieth century, scientists and politicians began to talk about the crisis of the welfare state. The collapse of the socialist system and the need to assist the countries of the former socialist camp who were looking to integrate into the world market economy were important factors in deepening the crisis. The global financial crisis of 2008 and the increasing volatility of global economic development should also be considered. Today, despite the financial and social differences between European countries, many of them have outstanding debt accompanied by a low economic growth rate. Seeking to maintain a high level of well-being and social protection, they are unable to reduce social security contributions, which could provoke a wave of protests and dissatisfaction with the state. Consequently, a reduction in government contribution to the accumulation of capital can be seen, first and foremost, by reducing investments in infrastructure and innovative projects, which slows down innovation progress as a whole.

Furthermore, the migration crisis, the ever-increasing financial liabilities associated with the aging of the European population, and the need to increase healthcare contributions should be added. The combination of the relatively free movement of skilled labor and high standards of state social security leads to increased unemployment and corresponding financial pressure on the public sector, exacerbating the current crisis and demographic problems that are addressed by attracting workers from overpopulated countries. The welfare state crisis is also manifested in the widespread disparity in income distribution, the narrowing of the middle class, and considerable separation of the population. Summarizing these trends, we can distinguish the following signs of the welfare state crisis:

1. Reducing public expenditures on social security in most European countries after the global financial and economic crisis, with relatively stable levels or a slight growth in countries such as Estonia, Germany, Latvia, Lithuania, Luxembourg, Poland, and Switzerland (Figure 1). 


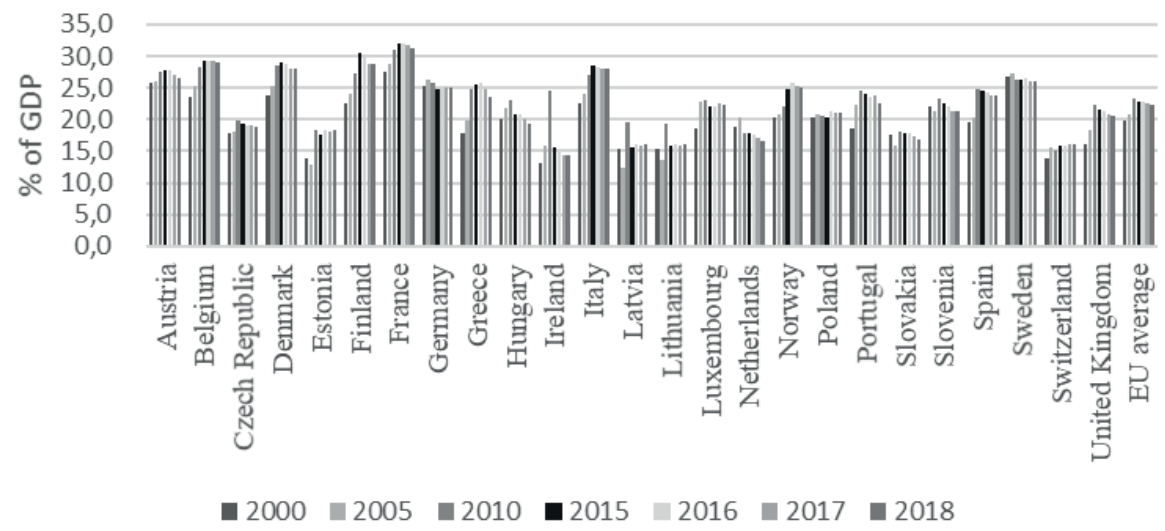

Figure 1. Government social expenditures (\% of GDP)

Source: authors' own elaboration based on data from The World Bank (2020).

One of the factors behind these processes within the EU was the increase in assistance to financially fragile countries. According to 2018 data, 12 European countries have a national budget deficit, which varies between $2.5 \%$ of GDP (Spain and France) to $0.2 \%$ of GDP (Poland), and they require financial assistance from partner countries to balance their budgets. Countries with government surpluses (the Netherlands with a surplus of $1.5 \%$, Germany with $1.9 \%$, and Luxembourg with $2.7 \%$ of GDP) play the role of creditors in this situation, providing financial resources to stabilize their more vulnerable European partner countries (Figure 2).

3,0

2,0

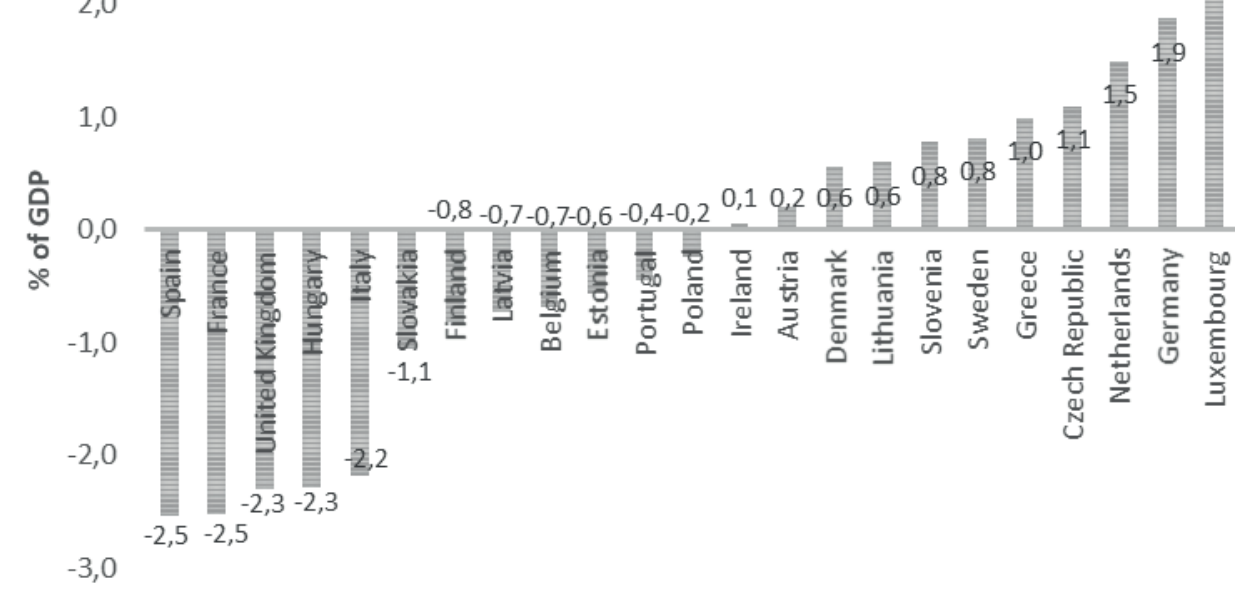

Figure 2. Government budget balance (\% of GDP), 2018

Source: authors' own elaboration based on OECD (2020). 
2. The lack of a visible correlation between the share of public expenditures (\% of GDP) and the equality of income distribution among the population. An analysis of the relationship between the ratio of the total income of the richest $10 \%$ to the poorest $10 \%$ of the population to the level of public social expenditure as a share of GDP as of 2017 confirms that increased public social spending is not accompanied by a proportional improvement in the distribution of income among the population (Figure 3).

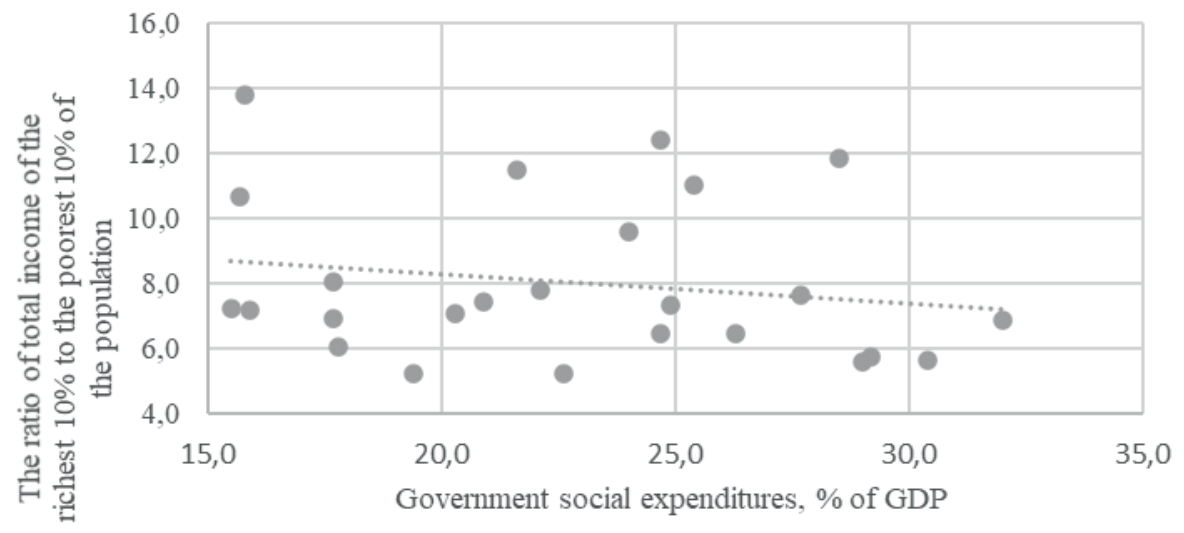

Figure 3. The relationship between income distribution and the level of government social expenditures, 2017

Source: authors' own elaboration based on Brien et al. (2019) and The World Bank (2020).

3. The inefficiency of state social expenditures. At present, there is a steady increase in the needs and expectations of society regarding the volume and list of public sector services and guarantees that are associated with an aging population. The data presented in Figure 4 on the volume (as a share of GDP) and types of public social expenditures (pensions and expenditures for the workable population), the volume of public financing of social services (as a share of GDP), and the share of health care expenditures as of 2017 confirm that in most European countries, a large part of the financial contribution to social needs goes to paying pensions and providing health services. The highest government expenditures for the working-age population (\% of GDP) are observed in Belgium (7.5\%), Finland (6.6\%), and Norway (6\%). At the same time, the share of expenditure on the medical care of older people prevails as a specified group of people in need of more medical services than citizens of working age. 
The Development of Corporate Social Responsibility...

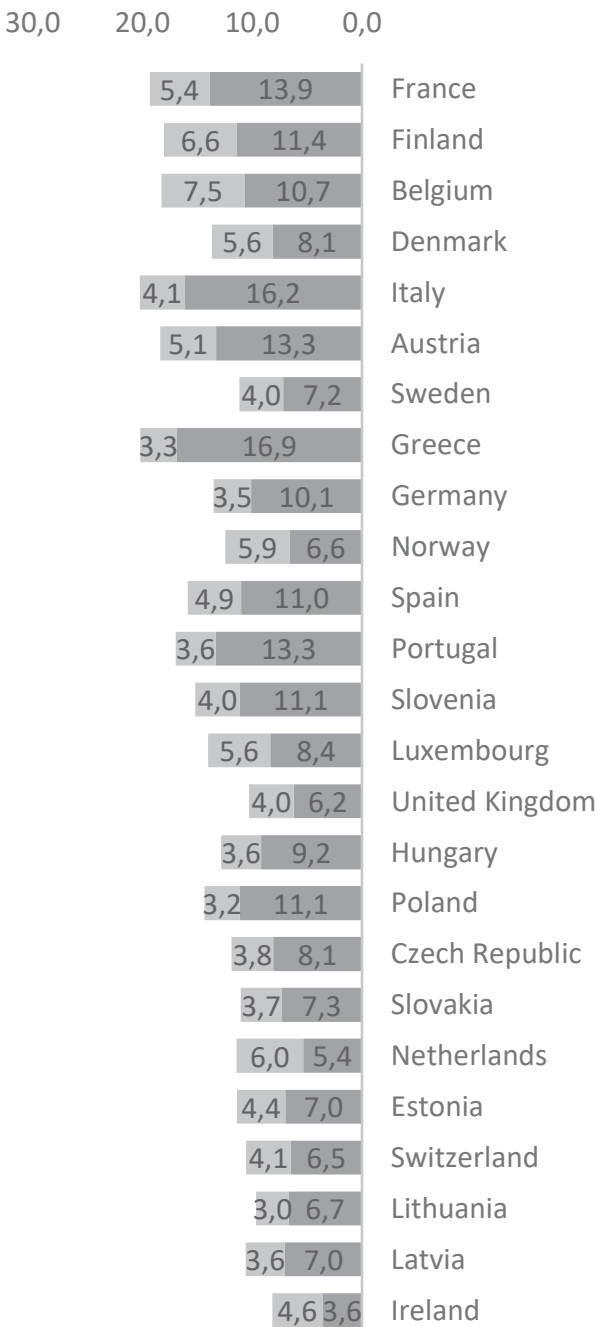

- Pensions

Income support to the working age population

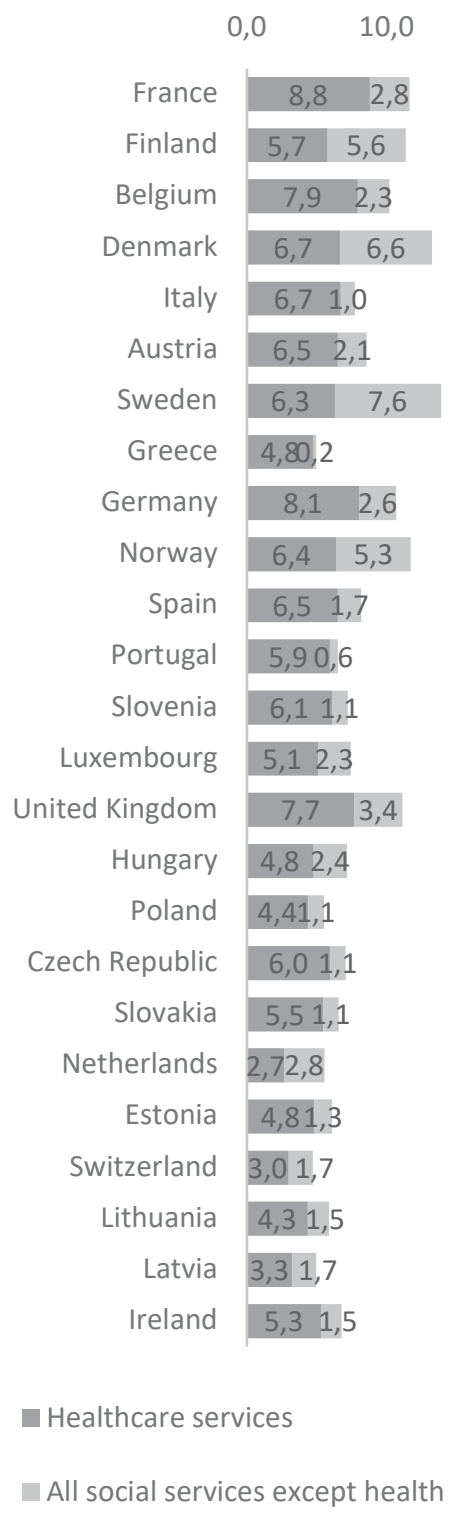

Figure 4. The distribution of government financial support and social services (\% of GDP), 2017/2018 Source: authors' own elaboration based on OECD (2020).

4. The European migration crisis, which began in 2015 when 1,322,825 asylum applications were received in EU countries, most of which were directed to Germany (36\% of all applications), Hungary (13.4\%), Sweden (12.3\%), Austria (6.6\%), Italy (6.3\%) and France (5.8\%). In 2016, however, the number of applications decreased to $1,259,955$, with $59.1 \%$ of applicants seeking asylum in Germany, $9.8 \%$ in Ita- 
ly, and $6.7 \%$ in France. In 2017, the number of applicants decreased almost twice to 705,705 (to Germany - 31.5\%, Italy - 18.3\%, and France - 14.1\%) (Eurostat 2020). These preferences of countries are driven by the difference in the social and financial security of asylum seekers. In particular, in Germany, each applicant receives financial assistance of 354 EUR per month, in Italy - 75 EUR per month, Sweden - 225 EUR per month, France - 204 EUR per month, and in Spain - 50 EUR per month during the asylum application period (Hodali and Prange 2018). This results in increased financial pressure on the state budget and the social commitments of economically stable European countries, which decided at the legislative level to provide certain social guarantees and financial assistance to refugees and individuals who were forced to leave their country of origin.

These transformations contribute to modifying the place and role of the state in today's global economy. It is a transition from social protection, based on the state's redistributive functions, to an active social policy aimed at stimulating high-productivity employment and activating the economic self-sufficiency of different segments of the population, based on realizing the benefits formed by the market mechanism. According to some researchers, there is a tendency to form a service state, which, unlike the welfare state, does not ensure economic equality of the population but provides equal educational, medical, and other services, thus, investing in social and human capital. Accordingly, the level of individual well-being is determined solely by the persistence of citizens, and financial social assistance is provided only to the needy (Golovashchenko 2016).

Important functions of the service state are to ensure environmental safety, promote competition and personal development, develop social partnerships, and actively engage with civil society institutions, which affect the effectiveness of the performance of the whole society, not just certain individuals. The public sector is therefore being reformed in many socially-oriented countries to narrow down the list of social services the state provides and to reduce government expenditures accordingly, as they are inefficient and do not bring the expected returns. Additionally, they should promote the activity and responsibility of citizens for their own well-being by creating conditions for self-development (Khoma 2014).

In our opinion, an important way to overcome the welfare state crisis is the voluntary involvement of business in solving social problems in the form of corporate social responsibility (CSR). It is about a socially-oriented business activity that can directly influence the redistribution of income in society, solving pressing social problems, implementing educational and cultural projects, developing local infrastructure, providing social protection and insurance for employees, and financing their training.

Today, such activities help meet the needs and expectations of all stakeholders (Piasecki and Gudowski 2017). Moreover, it is about recognizing the important role of human, intellectual, and social capital as the newest factors in the global competitiveness of individual companies and the national economy as a whole. Thus, according to the data presented in Figure 5, there is a direct correlation between the level of gov- 
ernment social expenditures (\% of GDP) and the level of social capital accumulation. At the same time, as our previous research showed, the development of CSR is also an important factor in social capital accumulation, through the creation and promotion of trustful relationships among stakeholders (Bazylevych et al. 2019).

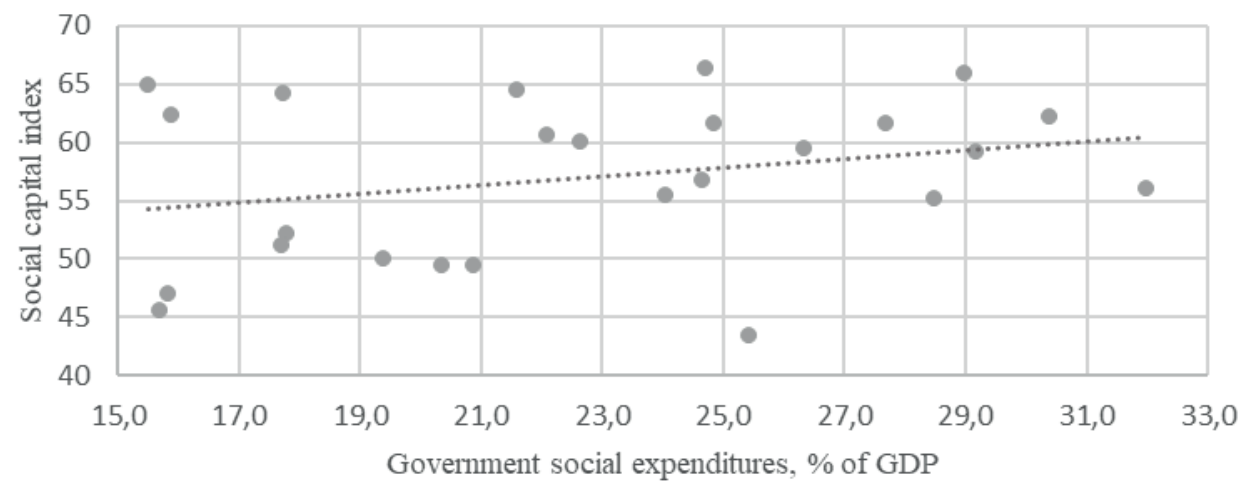

Figure 5. The relationship between government social expenditures (\% of GDP) and social capital index, 2018

Source: authors' own elaboration based on Brien et al. (2019) and The World Bank (2020).

Corporate social responsibility implies business responsibility in four main areas: economic (the production of goods and services that are demanded by society), legal (the functioning of business in accordance with current legislation), ethical (the protection of the rights of employees, consumers and other stakeholders beyond the requirements stipulated by law) and voluntary (business response to the expectations and social needs of society, addressing such global social problems as poverty, hunger, and discrimination) (Carroll 1979).

The implementation of the basic principles of CSR helps to solve many social problems through: 1) providing social support and protecting human rights (employees, consumers, suppliers); 2) charity or other forms of voluntary financial participation in solving pressing social national or local community problems; 3) encouraging employees to participate in charity projects and volunteering; 4) greening of the activity, which is seen in the transition to alternative energy sources and technologies with a minimum negative impact on the environment, the reuse of materials and the principles of zero waste production (Mikołajek-Gocejna 2018).

As mentioned above, CSR development contributes to the accumulation of social capital by building trusting relationships through following the principles of business ethics towards consumers, employees, partners, and the environment, providing honest information on product characteristics, reporting on social activity, and organizing or involving business in training and sports events for employees and their families and the local community, among others. At the same time, it is about raising tax revenues, as the social orientation of commercial activity leads to increased profitability, as well as the improved global competitiveness of the economy by forming loyal busi- 
ness relations with consumers and suppliers, gaining competitive advantages in the international market, accumulating the new forms of capital, and launching innovative environmentally friendly technologies.

\section{Analysis and results}

Ensuring the social orientation of the economic development of states requires the active involvement of business in this process. It is about developing corporate social responsibility as an important factor in overcoming the general welfare crisis, which is linked to reducing social expenditures accompanied by government deficits. In order to identify groups of countries that implement such a policy, the authors clustered 23 European countries by state social expenditure (\% of GDP), government budget balance (\% of GDP), and the level of CSR development (number of companies adhering to the relevant principles) for 2018.

\section{Cluster Dendrogram}

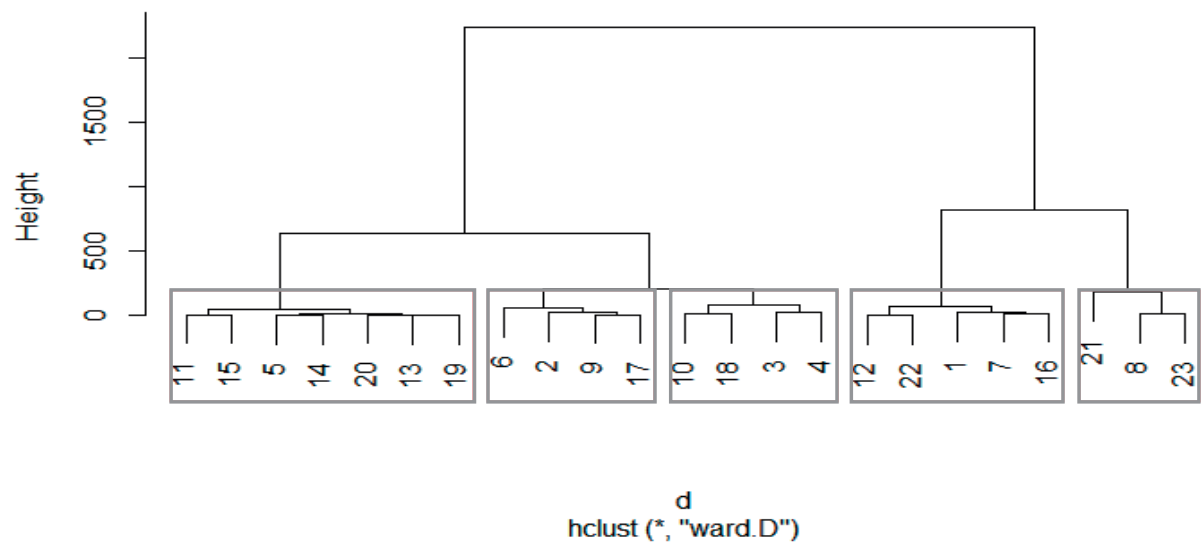

(1-Austria; 2-Belgium, 3-Czech Republic, 4-Denmark, 5-Estonia, 6-Finland, 7-France, 8-Germany, 9-Greece, 10-Hungary, 11-Ireland, 12-Italy, 13-Latvia, 14-Lithuania, 15-Luxembourg, 16-Netherlands, 17-Poland, 18-Portugal, 19-Slovakia, 20-Slovenia, 21-Spain, 22-Sweden, 23-United Kingdom)

Figure 6. Cluster analysis outcome Source: conducted by the authors.

The results of the analysis (Figure 6 and Table 1) allowed us to distinguish five groups of countries:

1) the countries of the first group (Estonia, Ireland, Luxembourg, Latvia, Lithuania, Slovakia, and Slovenia) are characterized by a positive balance of the state budget ( $0.26 \%$ of GDP on average), social expenditures at $18 \%$ of GDP, and the lowest level of CSR development (about 17 companies reported on implemented CSR projects on average). The level of income distribution in these countries 
averages $30.5 \%$ and varies from $24.1 \%$ (Slovakia) to $37.8 \%$ (Lithuania). The level of social capital development of these countries is within 45.5 (Latvia) and 64.9 (Ireland) with an average index value of 54.46;

2) countries of the second group (Finland, Belgium, Greece, and Poland) are characterized by high levels of government social contributions (25.55\% of GDP on average), low levels of government deficit ( $0.18 \%$ of GDP), and medium levels of CSR (153 companies published non-financial reports, on average). In addition, this group of countries has a low level of income disparity ( $28.7 \%$ on average), and the level of social capital development in these countries is 53.52;

3) the third group of countries (Hungary, Portugal, the Czech Republic, and Denmark) have relatively low social security (22.19\% of GDP), low government deficit $(0.2 \%$ of GDP), and low CSR development ( 85 companies reported on CSR, on average). These countries are characterized by a low level of income differentiation (28.2\% on average) and a medium level of social capital development (55.18);

4) the fourth group of countries (Italy, Sweden, Austria, France, the Netherlands) has the highest level of social protection (25.7\% of GDP, on average), a national deficit of $0.44 \%$ of GDP (on average), and a relatively high level of CSR development (266 socially responsible companies on average). At the same time, the level of income distribution in these countries averages $29.4 \%$, and the level of social capital development is 59.28 ;

5) the fifth group of countries (Spain, Germany, and the United Kingdom) is characterized by state social security expenditures at $23.15 \%$ of GDP, on average, a budget deficit at $0.97 \%$ of GDP (on average), and a high level of CSR development (about 500 companies on average). The income distribution in these countries is less equal (33.1\% on average), but the level of social capital development is higher than in the other groups of countries (60.93 on average).

Thus, the cluster analysis confirmed the importance of CSR development as a compensator for the negative effects of the public welfare crisis and for solving pressing social problems in most European countries. As for the countries of the former socialist camp, they show certain peculiarities in the context of the problem under study. An analysis of the development practices of Slovakia, Slovenia, Poland, Hungary, and the Czech Republic showed the following characteristics:

1) significantly lower government expenditure on social protection (17\% of GDP in Slovakia, $18.7 \%$ in the Czech Republic, and $19.4 \%$ in Hungary) compared to the average level in developed European countries (around 25\% of GDP);

2) a low level of CSR development. The lowest level of CSR development is observed in Slovenia (17 companies) and Slovakia (13 companies). At the same time, the highest results are achieved by Hungary and Poland, which have 114 and 141 companies, respectively, that report on their social activities. These figures are low compared to Italy and Sweden (287 and 288 companies). 
Table 1. Characteristics of clusters of European countries, 2018

\begin{tabular}{|c|c|c|c|c|c|}
\hline Countries & $\begin{array}{c}\text { Government social } \\
\text { expenditures } \\
\text { (\% of GDP) }\end{array}$ & $\begin{array}{c}\text { Government } \\
\text { budget balance } \\
\text { ( } \% \text { of GDP) }\end{array}$ & $\begin{array}{c}\text { CSR } \\
\text { development } \\
\text { (number of firms) }\end{array}$ & $\begin{array}{c}\text { Gini } \\
\text { index }\end{array}$ & $\begin{array}{l}\text { Social } \\
\text { capital } \\
\text { index }\end{array}$ \\
\hline \multicolumn{6}{|c|}{$1^{\text {st }}$ cluster } \\
\hline $\begin{array}{l}\text { Estonia } \\
\text { Ireland } \\
\text { Luxembourg } \\
\text { Latvia } \\
\text { Lithuania } \\
\text { Slovakia } \\
\text { Slovenia }\end{array}$ & 17.96 & 0.26 & 16.71 & 0.305 & 54.46 \\
\hline \multicolumn{6}{|c|}{$2^{\text {nd }}$ cluster } \\
\hline $\begin{array}{l}\text { Finland } \\
\text { Belgium } \\
\text { Greece } \\
\text { Poland }\end{array}$ & 25.55 & -0.18 & 153.00 & 0.287 & 53.52 \\
\hline \multicolumn{6}{|c|}{$3^{\text {rd }}$ cluster } \\
\hline $\begin{array}{l}\text { Hungary } \\
\text { Portugal } \\
\text { Czech Republic } \\
\text { Denmark }\end{array}$ & 22.19 & -0.20 & 85.50 & 0.282 & 55.18 \\
\hline \multicolumn{6}{|c|}{$4^{\text {th }}$ cluster } \\
\hline $\begin{array}{l}\text { Italy } \\
\text { Sweden } \\
\text { Austria } \\
\text { France } \\
\text { Netherlands }\end{array}$ & 25.69 & -0.44 & 266.60 & 0.294 & 59.28 \\
\hline \multicolumn{6}{|c|}{$5^{\text {th }}$ cluster } \\
\hline $\begin{array}{l}\text { Spain } \\
\text { Germany } \\
\text { United Kingdom }\end{array}$ & 23.15 & -0.97 & 495.67 & 0.331 & 60.93 \\
\hline
\end{tabular}

Source: designed by the authors.

\section{Conclusion}

The historical and systematic analysis showed that the first interpretation of the concept of a welfare state was formed by socialist scholars in the nineteenth century to minimize the negative effects of the industrial revolution. However, the concept transformed following historical circumstances and the needs of the state and population.

Later, the Great Depression had a significant impact on the theory and practice of state social policy. Following Roosevelt's "Second New Deal," the state social protection system was strengthened by establishing a social insurance scheme and expanding the social rights and guarantees of employees. 
In post-World War II Germany, the concept of a "social market economy" was formed, and it was defined as the combination of market freedoms with the principle of social equalization through rational fiscal policy. The policy aimed to give financial support to the population who had suffered losses as a result of the war, payments and subsidies to socially disadvantaged groups, and provide social security and preferential loans.

Next, the economic crisis of the 1970s affected and transformed the socio-economic policies of the world's leading countries towards liberalizing the economy and reducing many social programs. At the end of the twentieth century, the crisis of the welfare state began. The collapse of the socialist system and the need to assist the countries of the former socialist camp who were looking to integrate into the world market economy were important factors in deepening the crisis.

In addition, the global financial crisis of 2008 and the increasing volatility of global economic development were causing economic instability and the lack of social protection of the population. Moreover, the migration crisis, the ever-increasing financial liabilities associated with the aging of the European population, and the need to increase healthcare contributions should be added. The combination of the relatively free movement of skilled labor and high standards of state social security led to increased unemployment and corresponding financial pressure on the public sector. It exacerbated the current crisis and demographic problems that are addressed by attracting workers from overpopulated countries. Also, the welfare state crisis can be seen in the widespread disparity in income distribution, the narrowing of the middle class, and the considerable separation of the population.

Thus, during the present welfare state crisis, the delegation of some state social functions to the private sector in the form of corporate social responsibility helps to overcome negative consequences. When the private sector undertakes certain state social functions, it reduces the financial pressure on the budget, contributes to solving urgent social and environmental problems, stimulates the accumulation of new forms of capital, enhances the country's global competitiveness in the long run, and promotes population well-being.

At the same time, the cluster analysis for European countries proved the crucial role of CSR development as a compensator for the negative effects of the public welfare crisis and for solving pressing social problems.

For the countries of the former socialist camp, CSR development is an important direction of social policy transformation to optimize public expenditure and compensate for social losses related to radical socio-economic challenges and shocks due to market transformations and integration into the global economic environment. 


\section{References}

Aravacik, E.D. (2018), Social Policy and the Welfare State, IntechOpen, London, https:// www.intechopen.com/books/public-economics-and-finance/social-policy-and-the -welfare-state (accessed: 24.02.2020).

Bazylevych, V.D., Grazhevska, N.I., Mostepaniuk, A.V., Virchenko, V.V. (2019), Accumulation of social capital as a positive externality of corporate social responsibility development in transition economies, "Scientific Bulletin of National Mining University”, 1, pp. 132-140, https://doi.org/10.29202/nvngu/2019-1/19

Brien, S., Flanagan, S., Herring, D., Irving, H., Lee, J., McFahn, M., Pilsbury, S., Wickstead, E. (2019), The Legatum Prosperity Index 2019, https://www.prosperity.com/do wnload_file/view_inline/3690 (accessed: 24.02.2020).

Carroll, A.B. (1979), A three-dimensional conceptual model of corporate performance, "Academy of Management Review", 4 (4), pp. 497-505, https://doi.org/10.2307/25 7850

Chapman, B. (2007), The Police State, “Government and Opposition”, 3 (4), pp. 428 440, https://doi.org/10.1111/j.1477-7053.1968.tb01341.x

Esping-Andersen, G. (1990), The Three Worlds of Welfare Capitalism, Princeton University Press, Princeton, https://doi.org/10.1177/095892879100100108

Eurostat (2020), Asylum and first time asylum applicants by citizenship, age and sex Annual aggregated data (rounded), https://appsso.eurostat.ec.europa.eu/nui/show .do?dataset=migr_asyappctza\&lang=en (accessed: 24.02.2020).

Geissler, H. (1980), Sozialstaat. Kampfum Worter?, Politische Begriffe im Meinungsstreit, Wien.

Golovashchenko, O.S. (2016), The Social Law State and the challenges of globalization, "State Building and Local Government", 32, pp. 3-11.

Gordon, C. (1991), The Foucault Effect: Studies in Governmentality, University of Chicago Press, Chicago, https://laelectrodomestica.files.wordpress.com/2014/07/the-f oucault-effect-studies-in-governmentality.pdf (accessed: 24.02.2020).

Hodali, D., Prange, A. (2018), Asylum benefits in the EU: How member states compare, "Deutsche Welle", https://www.dw.com/en/asylum-benefits-in-the-eu-how-mem ber-states-compare/a-44298599 (accessed: 24.02.2020).

Keynes, J.M. (1936), The General Theory of Employment, Interest, and Money, Palgrave Macmillan, London, https://www.hetwebsite.net/het/texts/keynes/gt/gtcont.htm (accessed: 8.02.2021).

Khoma, N. (2014), Welfare state of the third millennium: upgraded models, "Scientific Notes of IPENR", 3 (71), pp. 205-215.

Kolev, S., Goldschmidt, N., Hesse, J.-O. (2014), Walter Eucken's role in the early history of the Mont Pèlerin Societ, https://www.econstor.eu/bitstream/10419/90809/1/7770 7169X.pdf (accessed: 20.02.2020).

Mauro, P., Romeu, R., Binder, A., Zaman, A. (2013), A Modern History of Fiscal Prudence and Profligacy, IMF Working Paper, https://doi.org/10.5089/9781616357825 .001 
Middleton, R. (1996), Government versus the Market: The Growth of the Public Sector, Economic Management and British economic performance, Edward Elgar, Cheltenham.

Mikołajek-Gocejna, M. (2018), The Environmental, Social and Governance Aspects of Social Responsibility Indices - A Comparative Analysis of European SRI Indices, "Comparative Economic Research. Central and Eastern Europe", 21 (3), pp. 25-44, https://doi.org/10.2478/cer-2018-0017

Niskanen, W.A. (1988), Reaganomics, https://www.econlib.org/library/Enc1/Reagano mics.html (accessed: 24.02.2020).

OECD Data (n.d.), https://data.oecd.org (accessed: 24.02.2020).

Piasecki, R., Gudowski, J. (2017), Corporate Social Responsibility: the Challenges and Constraints, "Comparative Economic Research. Central and Eastern Europe", 20 (4), pp. 143-157, https://doi.org/10.1515/cer-2017-0032

Rooks, T. (2019), Can Germany's social market economy system cope with another 70 years?, "Deutsche Welle", https://www.dw.com/en/can-germanys-social-market-e conomy-system-cope-with-another-70-years/a-50490937 (accessed: 24.02.2020).

Smiley, G. (n.d.), Great Depression, https://www.econlib.org/library/Enc/GreatDepres sion.html (accessed: 24.02.2020).

The World Bank Open Data (2020), https://data.worldbank.org/ (accessed: 24.02.2020).

United Nations (2015), Transforming our world: the 2030 Agenda for Sustainable Development, https://sustainabledevelopment.un.org/post2015/transformingourworld (accessed: 24.02.2020).

Urquhart, M.A., Hewson, M.A. (1983), Unemployment continued to rise in 1982 as recession deepened, https://stats.bls.gov/opub/mlr/1983/02/artlfull.pdf (accessed: 24.02.2020).

Volker, R.B. (2015), Ordoliberalism, Ludwig Erhard, and West Germany's "Economic Basic Law", "European Review of International Studies", 2 (3), pp. 37-47, https:// www.jstor.org/stable/26593477?seq=1 (accessed: 8.02.2021)

Zadoia, A., Palladin, A. (2017), Essay on the welfare State Models, "Scientific Bulletin of the Diplomatic Academy of Ukraine", 24 (3), pp. 14-18, http://ir.duan.edu.ua/bit stream/123456789/221/1/Nvdau_2017_24\%283\%29__4.pdf (accessed: 24.02.2020).

Zarnowitz, V., Moore, G.H. (1977), The Recession and Recovery of 1973-1976, "Explorations in Economic Research", 4 (4), pp. 471-557, https://www.nber.org/chapters /c9101.pdf (accessed: 24.02.2020). 


\section{Rozwój społecznej odpowiedzialności biznesu w kontekście przezwyciężenia kryzysu państwa opiekuńczego: próba analizy teoretycznej i empirycznej}

Obecny kryzys społeczny spowodowany negatywnymi konsekwencjami globalizacji, migracji zarobkowej i starzenia się społeczeństwa, wymaga ponownego rozważenia roli państwa w sferze gospodarczej i społecznej. Ponadto, w celu osiągnięcia i utrzymania trwałości wzrostu gospodarczego, należy rozwiązać zasadnicze problemy społeczne, takie jak ubóstwo, głód, dyskryminacja i nierówny podział dochodów. W tych okolicznościach praca ma na celu zbadanie procesu kształtowania się koncepcji państwa opiekuńczego w celu oceny roli dzisiejszych państw w okresie kryzysu społecznego. Aby osiągnąć cel pracy, zastosowano następujące metody: historyczną i systematyczną analizę literatury naukowej oraz społeczno-ekonomicznych uwarunkowań ewolucji teoretycznych ujęć państwa opiekuńczego, przyczyn i cech obecnego kryzysu społecznego; analizę skupień krajów europejskich w celu znalezienia podobnych wzorców na podstawie poziomu rozwoju społecznej odpowiedzialności biznesu (CSR), wydatków socjalnych państwa oraz salda budżetu państwa. Artykuł zawiera szczegółową analizę i omówienie powstawania koncepcji państwa opiekuńczego. Z badania wynika, że proces delegowania części państwowych usług socjalnych do sektora prywatnego w formie CSR można uznać za skuteczny mechanizm eliminacji i przezwyciężenia obecnego kryzysu społecznego poprzez akumulację kapitału społecznego. Jednocześnie wyniki przeprowadzonej analizy skupień krajów europejskich dowiodły znaczenia rozwoju CSR jako kompensatora negatywnych skutków kryzysu opieki społecznej i rozwiązywania palących problemów społecznych w większości krajów europejskich. Ponadto zwrócono uwagę na specyfikę krajów postsocjalistycznych w kontekście społecznej orientacji polityki państwa i rozwoju CSR.

Słowa kluczowe: państwo opiekuńcze, kryzys społeczny, polityka społeczna, opieka społeczna, społeczna odpowiedzialność biznesu 